\title{
FERRITES AS ADSORBENTS: REVIEW
}

\author{
Ivanenko I.M., Fedenko Yu.M., Lesik S.M., Kutsan N.V. \\ National Technical University of Ukraine \\ "Igor Sikorsky Kyiv Polytechnic Institute" \\ 37, Peremohy ave., 03056, Kyiv \\ fedenkoyura@ukr.net
}

Different methods are used to remove toxic dyes and synthetic substances from wastewater, such as adsorption, decomposition, photocatalysis, precipitation, coagulation, filtration, etc. Among the known removal methods, adsorption combined with the method of magnetic separation is promising due to its ease of operation, high efficiency and low cost.

A literary review on the synthesis of ferrite spinels and the study of their photocatalytic and sorption properties is presented. It has been established that in recent years, to further enhance the adsorption capacity of ferrite adsorbents in relation to chemical pollutants, research has mainly focused on the following two points: synthesis of ferrite nanomaterials different in morphology to increase the specific surface area, such as nanospheres, nanowires and nanostructures; synthesis of surface-modified ferrite composites, such as polymer-coated ferrite nanocomposites.

The influence of the ratio of ferrite: carbon carrier on the photocatalytic and sorption properties of the formed composites has been analyzed from the considered works. It is revealed that the chemical composition of ferrite spinel largely determines their ability to sorption of heavy metals, in particular of dime and synthetic dyes (methylene blue), due to the high value of their specific surface area, economy, high removal efficiency and the unique advantage of easy separation. magnetic field. The adsorption efficiency of ferrite spinels and alkaline-activated paligorskite was compared on the example of a methyl blue dye.

The effect of $\mathrm{pH}$ of the investigated solutions on the adsorption capacity of magnetic nanocomposites in relation to copper ions, as well as the dependence of the adsorption of methylene blue on the duration of contact with magnetic composites $\mathrm{Fe}_{3} \mathrm{O}_{4} @ \mathrm{C}$ was analyzed. It is established that the efficiency of adsorption by magnetic composites increases with increasing pH of adsorbate solutions in all studied cases. It has been found that magnetic adsorbents have indisputable advantages over traditional ones not only due to their high adsorption capacity, but also due to the possibility of their separation from the purified solutions by the method of magnetic separation. Key words: composite, nanoparticles, sorption, ferrite, photocatalysis, spinel.

Ферити як адсорбенти: огляд. Іваненко І.М, Феденко Ю.М., Лесік С.М., Куцан Н.В.

Для видалення токсичних барвників і синтетичних речовин зі стічних вод застосовуються різні методи, такі як адсорбція, розкладання, фотокаталіз, осадження, коагуляція, фільтрація. Відомим методом видалення є адсорбція, поєднана $з$ методом магнітного розділення. Вона є перспективною завдяки простоті ії експлуатації, високій ефективності і низькій вартості.

Представлено літературний огляд, присвячений синтезу феритних шпінелей і дослідженню їх фотокаталітичних і сорбційних властивостей. Встановлено, що останніми роками для подальшого підвищення адсорбційної здатності феритних адсорбентів щодо хімічних забруднювачів дослідження здебільшого зосереджені на двох таких моментах: синтез різних за морфологією феритних наноматеріалів для збільшення питомої поверхні (наносфери, нанопроволоки, наностержні і нанолисти); синтез модифікованих на поверхні феритних композитів, таких як нанокомпозити з полімерним покриттям фериту.

Проаналізовано вплив співвідношення ферит-вуглецевого носія на фотокаталітичні та сорбційні властивості утворюваних композитів. Виявлено, що хімічний склад феритових шпінелей здебільшого визначає їхню здатність до сорбції важких металів, зокрема йонів купруму та синтетичних барвників (метиленовий синій), завдяки високому значенню питомої площі їх поверхні, економічності, високій ефективності видалення і унікальній перевазі легкого розділення під впливом зовнішнього магнітного поля.

Проведено порівняння адсорбційної ефективності феритових шпінелей та лужно-активованого палигорськіту на прикладі полютанта - барвника метиленового синього. Проаналізовано вплив $\mathrm{pH}$ досліджуваних розчинів на адсорбційну ємність магнітних нанокомпозитів по відношенню до йонів купруму, а також залежність адсорбції метиленового синього від тривалості контакту 3 магнітними композитами $\mathrm{Fe}_{3} \mathrm{O}_{4} @ \mathrm{C}$. Встановлено, що ефективність адсорбції магнітними композитами зростає при збільшенні рН розчинів адсорбатів в усіх досліджених випадках. 3'ясовано, що магнітні адсорбенти мають безперечні переваги перед традиційними завдяки не тільки високій адсорбційній ємності, а й можливості їх відділення від очищуваних розчинів методом магнітної сепарації. Ключові слова: композит, наночастинки, сорбція, ферит, фотокаталіз, шпінель.

Introduction. Today, there is a growing interest in the studying and usage a new sorption materials. The advantage of the latter is the ability of the adsorbent to regenerate and work without the formation of sediment [1], and the process of adsorption purification of water is a simple and convenient method.

Many researchers are developing a series of new adsorption materials and new methods of water purification. Different methods are used to remove toxic dyes and synthetic substances from wastewater, such as adsorption, decomposition, photocatalysis, precipitation, coagulation and filtration, etc. [2-4]. Among them, adsorption based on the method of magnetic separation has been found to be excellent due to its ease of operation, high efficiency and low cost [5].

Spinel ferrite (SF) is one of the most famous classes of magnetic materials. The general formula of spinel ferrites is $\mathrm{MFe}_{2} \mathrm{O}_{4}$. In this formula, $\mathrm{M}$ is a cation of a diva- 
lent metal such as $\mathrm{Co}^{2+}, \mathrm{Zn}^{2+}, \mathrm{Ni}^{2+}, \mathrm{Fe}^{2+}, \mathrm{Mn}^{2+}, \mathrm{Mg}^{2+}$ etc [6-9]. Spinel ferrites have excellent properties due to their structural properties, high electrical resistance, low conductivity and low dielectric losses [10-12].

The exceptional properties of SFs make them promising materials for use as adsorbents [13-15], sensors [16-19], magnetic devices [20], rechargeable batteries [21], photocatalysts [22-23], etc. The usage of SFs in water treatment as adsorbents for the purification of toxic contaminants from the aquatic environment is of particular interest. BF has been widely studied as adsorbents because their unique physicochemical properties differ from their analogues. SFs can be made with variable size and shape, versatility of the surface (easy to operate with different ligands), high surface-to-volume ratio and tuned magnetic properties. These wonderful properties of SFs can guarantee their durability.

Investigation of photocatalytic properties. The authors of [10] synthesized mixtures of ferrite nanoparticles of various sizes, which were investigated for potential use as photocatalysts and biological catalysts. In determining the practical and relevant structure-property correlations, the authors used a combination of SQUID and Mesbauer methods to explain this data to systematically correlate the size and composition of nanoparticles with the observation of the magnetic behavior of nanoparticles. In doing so, they found that superparamagnetism is only present in ultra-small nanoparticles $(\leq 4,0 \mathrm{~nm})$ with very low magnetic saturation values. The presence of spin slopes, uncompensated surface spins and magnetic anisotropy was observed for most samples; freezing temperatures and freezing temperatures associated with these systems were also discussed.

Silica-modified cobalt ferrite magnetic nanostructured composite, the authors of [11], obtained by wet chemical method. The silica-modified $\mathrm{CoFe}_{2} \mathrm{O}_{4}$ composite (CZFS) was studied in terms of its adsorption properties (with respect to $\mathrm{MC}$ and $\mathrm{Mn}^{+}$model solutions) in comparison with CZF and CF samples prepared without modification of silica and $\mathrm{Zn}^{2+}$ silica, respectively. A higher surface area of SBET = $59,8 \mathrm{~m}^{2} / \mathrm{g}$ CZFS (mesopores with $\mathrm{D}=8,5 \mathrm{~nm}$ ) compared to $\mathrm{CZF}$ and $\mathrm{CF}$ together with a high $\zeta=-35,4 \mathrm{mV}$ leads to improved MS adsorption capacity compared to $\mathrm{CZF}$ and $\mathrm{CF}$. The adsorption of MS by CZFS (for $\mathrm{C}_{0}=5-25 \mathrm{mg} / \mathrm{dm}^{3}$ ) is well in line with the Langmuir model, supporting an almost homogeneous CZFS surface with predominantly equivalent sites for MS adsorption. CZFS can be effectively used as an adsorbent of MS and $\mathrm{Mn}^{+}$up to three cycles.

The authors of [18] found that cobalt ferrite nanoparticles aggregated with schwertmannite (CNSh) is a potential adsorbent for the removal of arsenic from water. It has been found that arsenic sorption by CNSh is strongly $\mathrm{pH}$ dependent. More than $95 \%$ of arsenic was adsorbed at initial arsenic concentrations up to $200 \mathrm{~g} / \mathrm{dm}^{3}$ with using a dosage of adsorbent of $1 \mathrm{~g} / \mathrm{dm}^{3}$ during 240 minutes. The percentage of adsorption gradually decreased with increasing initial concentration of arsenic. Thermodynamic studies have shown that the process of adsorption of arsenic is spontaneous and endothermic with a value of $\mathrm{H} 5,3 \mathrm{~kJ} / \mathrm{mol}$, which confirms the physicochemical process of adsorption.

It was found that the second-order pseudo-kinetic model is in best agreement with the experimental data for arsenic adsorption. The equilibrium study showed the correspondence of the Langmuir isotherm model and not the Freundlich isotherm model with an adsorption capacity of $10-11 \mathrm{~g} / \mathrm{g}$, indicating the adsorption of the monolayer on the surface of the nano-adsorbent. The spent adsorbents were recovered by $\mathrm{NaOH}$ solutions, and the recovered adsorbents showed very good adsorption efficiency. The prepared adsorbent can be selected as an alternative to the existing one used to remove arsenic.

Compared to other sorbents, nanoscale magnetic materials have a high ability to adsorb $\mathrm{Cu}$ (II) ions due to their large surface area, cost-effectiveness, high removal efficiency, and the unique advantage of easy separation under the influence of an external magnetic field [24-26]. Magnetic nanoparticles attract close attention when removing heavy metals from wastewater [27], such as arsenic, lead, mercury, chromium, cadmium and copper, which are known to cause serious damage to living organisms and the environment [28-29].

In recent years, to further enhance the adsorption capacity of ferrite adsorbents in relation to chemical pollutants, research has focused mainly on the following two points: synthesis of various morphological ferrite nanomaterials to increase the specific surface area, such as nanospheres, nanowires, nanorods and nanostructures; synthesis of surface-modified ferrite composites, such as polymer-coated ferrite nanocomposites. Here, the polymer coating on the surface of the ferrite is used to remove certain classes of contaminants, and the ferrite nanoparticles are used to complete the magnetic separation. The authors of [30] synthesized modified polylysine nanoparticles of $\mathrm{Fe}_{3} \mathrm{O}_{4}$ and indicated that the adsorption capacity of the modified adsorbent for the anionic dye increased significantly.

Maine et al. chitosan-modified manganese ferrite nanoparticles were synthesized and used for adsorption of $\mathrm{Cu}^{2+}$ ions from wastewater [31]. However, only a few studies address the micro-mechanisms of the polymer coating to change the microstructure of the ferrite nanoparticles and the physical nature of the polymer coating to enhance the adsorption capacity of the ferrite nanoparticles.

The authors of [31] also studied the effect of $\mathrm{pH}$ solution on the efficiency of the adsorption process. $\mathrm{pH}$ is an important operating parameter in the adsorption process because it affects the solubility of metal ions, the concentration of counterions on the functional groups of the adsorbent and the degree of ionization of the adsorbent during the reaction. Fig. 1 shows the effect of solution $\mathrm{pH}$ on the efficiency of adsorption 
of $\mathrm{Cu}^{2+}$ ions on magnetic nanoparticles at $27^{\circ} \mathrm{C}$ with initial concentrations of $\mathrm{Cu}^{2+} 100$ and $50 \mathrm{mg} / \mathrm{dm}^{3}$.

The adsorption efficiency increases with increasing $\mathrm{pH}$ of the solution in all three cases. It is noteworthy that the adsorption efficiency increases markedly with an increase in the $\mathrm{pH}$ of the solution from 3,5, and then gradually increases to a $\mathrm{pH}$ of 6,5 , especially for a solution with an initial concentration of $\mathrm{Cu}^{2+} 50 \mathrm{mg} / \mathrm{dm}^{3}$ ions. As shown in Fig. 1, the adsorption efficiency can reach $99,1 \%$ at the initial concentration of $\mathrm{Cu}^{2+} 50 \mathrm{mg} / \mathrm{dm}^{3}$ ions, $\mathrm{pH} 6,5$ and contact duration of 3 hours. When the $\mathrm{pH}$ is above 6,5 , a blue precipitate of $\mathrm{Cu}(\mathrm{OH})_{2}$ is formed, so no adsorption experiments were performed.

Methylene blue (MB) is the main dye used for histological, microbiological and tissue staining. When MB is exposed to ultraviolet, water and many chemicals, fading and decomposition are almost impossible due to its complex aromatic structures and sufficient water solubility. Thus, much effort was devoted to the removal of $\mathrm{MB}$ before discharge into the natural environment.

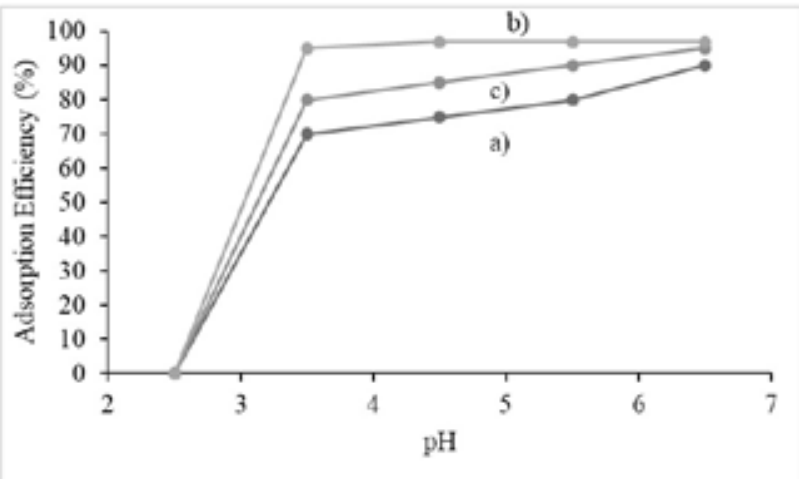

Fig. 1. Effect of solution $\mathrm{pH}$ on the efficiency of adsorption of $\mathrm{Cu}^{2+}$ ions by magnetic nanocomposites, with initial concentration of $\mathrm{Cu}^{2+}$ ions and contact duration: $a-100 \mathrm{mg} / \mathrm{dm}^{3}, 3$ years; $b-50 \mathrm{mg} / \mathrm{dm}^{3}$, 3 years; $c-50 \mathrm{mg} / \mathrm{dm}^{3}, 30 \mathrm{~min}[31]$

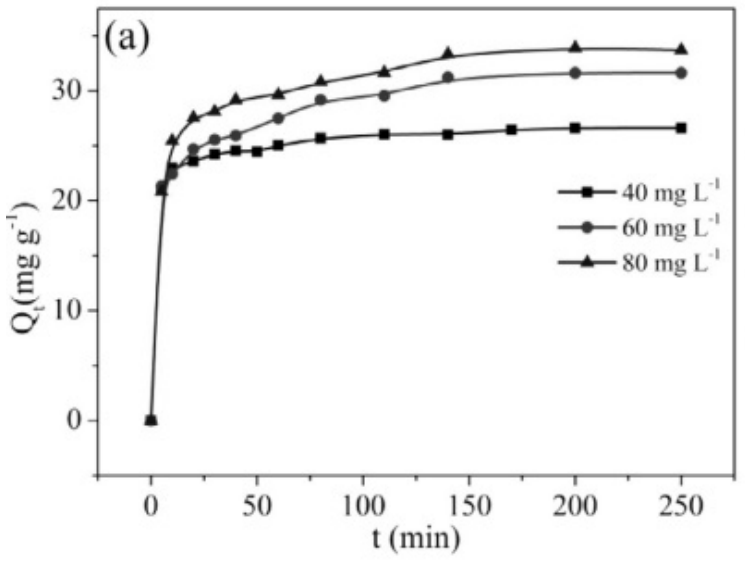

The authors of [32] made magnetic beads-type carbon nanospheres to remove methylene blue.

The adsorption properties of $\mathrm{Fe}_{3} \mathrm{O}_{4} @ \mathrm{C}$ composites were demonstrated by the choice of MS as a model pollutant. To understand the kinetics of adsorption, the effect of contact duration on the adsorption of $\mathrm{MB}$ by the $\mathrm{Fe}_{3} \mathrm{O}_{4} @ \mathrm{C}$ composite was first investigated by adding $10 \mathrm{mg}$ of sample to $10 \mathrm{ml}$ of MB solution $\left(40-80 \mathrm{mg} / \mathrm{dm}^{3}\right)$. After shaking for a predetermined interval, the magnetic particles were separated by magnetic separation and the corresponding concentrations of the dyes in the solutions were measured by UV-visible spectrometry. As can be seen in Fig. 2 a, the same tendency is observed on the adsorption curves, and all samples reach $>90 \%$ of the adsorption capacity at equilibrium for $30 \mathrm{~min}$. The amount of adsorbed MB increased significantly along with the initial concentration of $\mathrm{MB}$, which implies favorable adsorption even at high dye concentration.

The graph of the dependence of $\mathrm{t} / \mathrm{Qt}$ on the adsorption of $\mathrm{MB}$ at different initial concentrations was linear (Fig. 2b). These results demonstrated that the pseudo-second order model exhibits kinetic properties well $\left(\mathrm{R}_{2}>0,99\right)$ and indicates typical chemical adsorption. Adsorption progressed when the MS molecules first adsorbed the $\mathrm{Fe}_{3} \mathrm{O}_{4} @ \mathrm{C}$ carbon shell and then diffused into the cavity through the porous channel. MS was adsorbed on the surface of $\mathrm{Fe}_{3} \mathrm{O}_{4}$ by electrostatic gravity, since $\mathrm{MB}$ is a cationic dye, and some carboxyl groups derived from dehydrate trisodium citrate exist on the surface of $\mathrm{Fe}_{3} \mathrm{O}_{4}$. This process is similar to the diffusion of small molecules into cells through cell membranes.

Quote by others have proposed a photoelectron catalytic oxidation method for the removal of $\mathrm{MB}$ using $\mathrm{SnO}_{2} / \mathrm{Fe}_{2} \mathrm{O}_{3}$ electrodes [33].

As can be seen in Fig. 3, the decrease in $\mathrm{Cu}^{2+}$ content at the cathode was more influenced by the current density than the deterioration of the $\mathrm{MC}$ at the anode. Initially, the removal rates of $\mathrm{Cu}^{2+}$ and $\mathrm{MB}$ increased

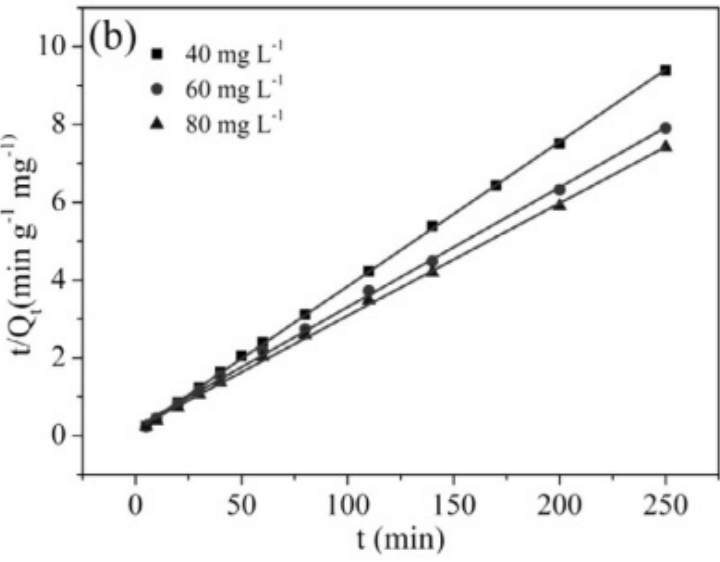

Fig. 2. Influence of contact duration and initial $M B$ concentration on $M B$ adsorption by $\mathrm{Fe}_{3} \mathrm{O}_{4} @ \mathrm{C}$ composite (a) and pseudo-second order MB kinetics adsorption on $\mathrm{Fe}_{3} \mathrm{O}_{4} @ C$ composite (b) [32] 


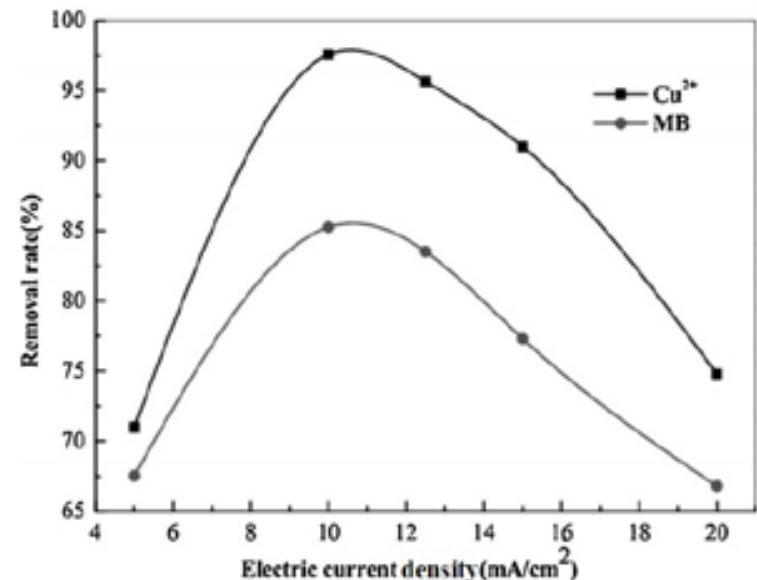

Fig. 3. Effect of electric current density on the removal of $\mathrm{MC}$ and $\mathrm{Cu}^{2+}[33]$

with increasing current density from $5 \mathrm{~mA} / \mathrm{cm}^{2}$ to $10 \mathrm{~mA} / \mathrm{cm}^{2}$, reaching maximum removal rates of $97,57 \%$ and $85,26 \%$ for $\mathrm{Cu}^{2+}$ and $\mathrm{MB}$, respectively. However, with a further increase in current density up to $20 \mathrm{~mA} / \mathrm{cm}^{2}$, the removal rate of both $\mathrm{Cu}^{2+}$ and $\mathrm{MB}$ decreased dramatically, since the limiting current density for this process is $20 \mathrm{~mA} / \mathrm{cm}^{2}$. In addition, when the current density exceeds $10 \mathrm{~mA} / \mathrm{cm}^{2}$, the reduction of $\mathrm{Cu}^{2+}$ at the cathode is limited due to interference from adverse reactions. Therefore, the removal rate of $\mathrm{Cu}^{2+}$ is affected. Therefore, $10 \mathrm{~mA} / \mathrm{cm}^{2}$ was chosen as the optimal current density for the subsequent studies.

The authors of [34] found enhanced adsorption removal of $\mathrm{MB}$ from an aqueous solution of alkaline-activated paligorskite (PAL). Alkaline activation was successfully introduced to enhance the adsorption capacity of PAL with respect to MB. It was found that metal ions in the crystalline PAL framework can be selectively removed by controlling the concentration of alkali solution. Interestingly, in addition to acid activation, the $\mathrm{Si}-\mathrm{O}-\mathrm{M}$ and $\mathrm{Si}-\mathrm{O}-\mathrm{Si}$ bonds were moderately broken in the alkaline activation process, which led to the creation of new adsorption centers. This effectively increases the surface negative potential of PAL and improves the adsorption properties for MB.

The PAL nanoparticle became shorter after alkaline activation at a lower concentration $\left(<5 \mathrm{~mol} / \mathrm{dm}^{3}\right)$. The rod-like morphology and specific surface area of BET PAL practically disappeared, with activation of a higher concentration of $\mathrm{NaOH}$ solution $\left(5,0 \mathrm{~mol} / \mathrm{dm}^{3}\right)$, which means that the pore structure was destroyed. Although the specific surface area of the PAL activated by $5 \mathrm{~mol} / \mathrm{dm}^{3} \mathrm{NaOH}$ solution is almost zero, it still has a much better adsorption capacity than the untreated PAL. From the above analysis, we can conclude that the adsorption is primarily affected not by the specific surface area, but by the interaction, such as electrostatic, complexing and hydrogen bonds. Activated PAL can decolorize MB in solution $\left(200 \mathrm{mmol} / \mathrm{dm}^{3}\right)$, which is far superior to untreated PAL. Another invention is that the PAL absorbed by MB exhibits higher stability and can be used to produce Mayan blue pigment, which provides a new approach to the sustainable usage of PAL adsorbents.

Dyes are widely used as colorants in industries such as textile, paper, food, printing, leather, plastic, pharmaceutical, and the like. To date, pollution of surface and groundwater by many species of dyes is a global environmental problem and a threat to humans and aquatic organisms [35]. Many treatments have been developed and applied, including electrochemical methods, oxidation or ozonation, membrane separation, photochemical decomposition, reverse osmosis, flocculation, coagulation, aerobic or anaerobic treatment and adsorption [34-36] have been developed and applied worldwide.

Conclusions. A literary review on the synthesis of ferrite spinels and the study of their photocatalytic and sorption properties is presented. It has been established that in recent years, to further enhance the adsorption capacity of ferrite adsorbents in relation to chemical pollutants, research has mainly focused on the following two points: synthesis of various morphological ferrite nanomaterials to increase the specific surface area, such as nanospheres, nanowires, nanorods, nanorods; synthesis of surface-modified ferrite composites, such as polymer-coated ferrite nanocomposites.

The influence of the ratio of ferrite: carbon carrier on the photocatalytic and sorption properties of spinels has been analyzed from the considered works. It is revealed that the chemical composition of ferrite spinels largely determines their ability to sorption of heavy metals, in particular dime, and synthetic dyes (methylene blue), due to the high value of their specific surface area, economy, high removal efficiency and the unique advantage of easy separation. magnetic field. A comparison of the sorption efficiency of ferrite spinels and alkaline-activated paligorskite is made on the example of a pollutant-methylene blue dye.

\section{References}

1. Y.-J. Chu, S.-Y. Hsiao, C.-C. Weo, C.-W. Liu, C.-M. Liao, F.-J. Chang, V.-C. Liao, W.-C. Shen, Arsenici Geosphere and Human Diseases; Arsenic 2010, CRCPress, Taylor\&Francis Group, Boca Raton. New-York, 2010. P. 556-557.

2. A. Mittal, A. Malviya, D. Kaur, J. Mittal, L. Kurup, Studies on the adsorption kinetics and isotherms for the removal and recovery of Methyl Orange from wastewaters using waste materials. J. Hazard. Mater. 2007. Vol. 148. P. 229-240.

3. N. Mohan, N. Balasubramanian, C. Ahmed Basha. Electrochemical oxidation of textile wastewater and its reuse. J. Hazard. Mater. 2007. Vol. 147. P. 644-651.

4. S.Y. Kim, J.Y. An, B.W. Kim. The effects of reductant and carbon source on the microbial decolorization of azo dyes in an anaerobic sludge process. Dyes Pigments. 2008. Vol. 76. P. 256-263. 
5. Y.J. Tu, C.F. You. Phosphorus adsorption onto green synthesized nano-bimetal ferrites: equilibrium, kinetic and thermodynamic investigation. Chem. Eng. J. 2014. Vol. 251. P. 285-292.

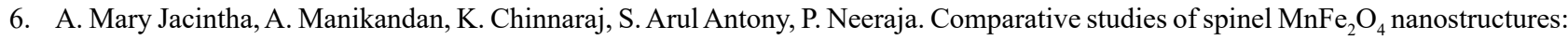
structural, morphological, optical, magnetic and catalytic properties. J. Nanosci. Nanotechnol. 2015. Vol. 15. P. 9732-9740.

7. E. Hema, A. Manikandan, M. Gayathri, M. Durka, S.A. Antony, B.R. Venkatraman. The role of $\mathrm{Mn}^{2+}$-doping on structural, morphological, optical, magnetic andcatalytic properties of spinel $\mathrm{ZnFe}_{2} \mathrm{O}_{4}$ nanoparticles. J. Nanosci. Nanotechnol. 2016. Vol. 16. P. 5929-5943.

8. M.M.L. Sonia, S. Anand, V.M. Vinosel, M.A. Janifer, S. Pauline, A. Manikandan. Effect of lattice strain on structure, morphology and magneto-dielectric propertiesof spinel $\mathrm{NiGd}_{x} \mathrm{Fe}_{2-\mathrm{x}} \mathrm{O}_{4}$ ferrite nano-crystallites synthesized by sol-gel route. J. Magn. Magn. Mater. 2018. Vol. 466. P. 238-251.

9. M. Amiri, M. Salavati-Niasari, A. Akbari. Magnetic nanocarriers: evolution of spinelferrites for medical applications. Adv. Colloid Interface Sci. 2019. Vol. 265. P. 29-44.

10. A.L. Tiano, G.C. Papaefthymiou, C.S. Lewis, J. Han, C. Zhang, Q. Li, C. Shi, A.M. Abeykoon, S.J. Billinge, E. Stach. Correlating size and composition-dependent effects with magnetic, mossbauer and pair distribution function measurements in afamily of catalytically active ferrite nanoparticles. Chem. Mater. 2015. Vol. 27 P. 3572-3592.

11. A. Sengupta, R. Rao, D. Bahadur. $\mathrm{Zn}^{2+}-$ Silica modified cobalt ferrite magnetic nanostructured composite for efficient adsorption of cationic pollutants from water. ACS Sustain. Chem. Eng. 2017. Vol. 5. P. 1280-1286.

12. E. Jaberolansar, P. Kameli, H. Ahmadvand, H. Salamati. Synthesis and characterization of PVP-coated $\mathrm{Co}_{0} \cdot 3 \mathrm{Zn}_{0} \cdot \mathrm{Fe}_{2} \mathrm{O}_{4}$ ferrite nanoparticles. J. Magn. Magn.Mater. 2016. Vol. 404. P. 21-28.

13. T.G. Glover, D. Sabo, L.A. Vaughan, J.A. Rossin, Z.J. Zhang. Adsorption of sulfur dioxide by $\mathrm{CoFe}_{2} \mathrm{O}_{4}$ spinel ferrite nanoparticles and corresponding changes in magnetism. Langmuir. 2012. Vol. 28. P. 5695-5702.

14. T.G. Glover, J.B. DeCoste, D. Sabo, Z.J. Zhang. Chemisorption of cyanogen chloride by spinel ferrite magnetic nanoparticles. Langmuir. 2013. Vol. 29. P. 5500-5507.

15. A. Dey, R. Singh, M.K. Purkait. J. Cobalt ferrite nanoparticles aggregated schwertmannite: a novel adsorbent for the efficient removal of arsenic. Water Process Eng. 2014. Vol. 3. P. 1-9.

16. Y.-L. Liu, Z.-M. Liu, Y. Yang, H.-F. Yang, G.-L. Shen, R.-Q. Yu. Simple synthesis of $\mathrm{MgFe}_{2} \mathrm{O}_{4}$ nanoparticles as gas sensing materials. Sensor. Actuat. B-Chem. 2005. P. 600-604.

17. R.H. Vignesh, K.V. Sankar, S. Amaresh, Y.S. Lee, R.K. Selvan. Synthesis and characterization of $\mathrm{MnFe}_{2} \mathrm{O}_{4}$ nanoparticles for impedometric ammonia gas sensor. Sensor. Actuat. B-Chem. 2015. P. 50-58.

18. A. Šutka, K.A. Gross. Spinel ferrite oxide semiconductor gas sensor. Sensor. Actuat. B-Chem. 2016. Vol. 222. P. 95-105.

19. J.Y. Patil, D.Y. Nadargi, J.L. Gurav, I.S. Mulla, S.S. Suryavanshi. Synthesis of glycine combusted $\mathrm{NiFe}_{2} \mathrm{O}_{4}$ spinel ferrite: a highly versatile gas sensor. Mater. Lett. 2014. Vol. 124. P. 144-147.

20. Y. Suzuki, Epitaxial Spinel Ferrite Thin Films. Annu. Rev. Mater. Res. 2001. Vol. 31. P. 265-289.

21. B.P. Hahn, J.W. Long, A.N. Mansour, K.A. Pettigrew, M.S. Osofsky, D.R. Rolison. Nanosized Mo-substituted cobalt ferrite $\mathrm{CoFe}_{2 \mathrm{x}} \mathrm{Mo}_{\mathrm{x}} \mathrm{O}_{4}$. Energ. Environ. Sci. 2011. Vol. 4. P. 1495-1502.

22. E. Casbeer, V.K. Sharma, X.-Z. Li. Synthesis and photocatalytic activity of ferrites under visible light: a review. Sep. Purif. Technol. 2012. Vol. 87. P. 1-14

23. D. Hong, Y. Yamada, M. Sheehan, S. Shikano, C.-H. Kuo, M. Tian, C.-K. Tsung, S. Fukuzumi. Mesoporous nickel ferrites with spinel structure prepared by an aerosol spray pyrolysis method for photocatalytic hydrogen evolution. Acs. Sustain. Chem. Eng. 2014. Vol. 2. P. 2588-2594.

24. I. Ali, Z.A. Alothman, A. Al-Warthan. Synthesis of composite iron nano adsorbent and removal of ibuprofen drug residue from water. J. Mol. Liq. 2016. Vol. 219. P. 858-864.

25. I. Ali, Z.A. Alothman, A. Al-Warthan. Green synthesis of functionalized iron nano particlesand molecular liquid phase adsorption of ametryn from water. J. Mol. Liq. 2016. Vol. 221. P. 1160-1174.

26. I. Ali, Z.A. Alothman, O.M.L. Alharbi. Uptake of pantoprazole drug residue from water using novel synthesized composite iron nano adsorbent. J. Mol. Liq. 2016. Vol. 218. P. 465-472.

27. H.A. Patel, J. Byun, C.T. Yavuz. Arsenic removal by magnetic nanocrystalline bariumhexa ferrite. J Nanopart Res. 2012. Vol. 14. P. 881.

28. N.V. Solenkova, J.D. Newman, J.S. Berger, G. Thurston, J.S. Hochman, G.A. Lamas. Metalpollutants and cardiovascular disease: mechanisms and consequences of exposure. AM Heart J. 2014. Vol. 168. P. 812-822.

29. J. Byun, H.A. Patel, C.T. Yavuz. Magnetic $\mathrm{BaFe}_{12} \mathrm{O}_{19}$ nanofiber filter for effective separation of $\mathrm{Fe}_{3} \mathrm{O}_{4}$ nanoparticles and removal of arsenic. J Nanopart Res. 2014. Vol. 16. P. 1-12.

30. Y.R. Zhang, P. Su, J. Huang, Q.R. Wang, B.X. Zhao. A magnetic nanomaterial modified with poly-lysine for efficient removal of anionic dyes from water. Chem.Eng. J. 2015. Vol. 262. P. 313-318.

31. Y.Y. Meng, D.Y. Chen, Y.T. Sun, D.L. Jiao, D.C. Zeng, Z.W. Liu. Adsorption ofCu ${ }^{2+}$ ions using chitosan-modified magnetic Mn ferrite nanoparticles synthesized by microwave-assisted hydrothermal method. Appl. Surf. Sci. 2015. Vol. 324. P. 745-750.

32. Y.M. Shao, L.C. Zhou, C. Bao, J.J. Ma. A facile approach to the fabrication ofrattle-type magnetic carbon nanospheres for removal of methylene blue in water. Carbon. 2015. Vol. 89. P. 378-391.

33. J.Q. Qi, X.C. Liu, H. Zheng, P.Q. Li, H.Y. Wang. Simultaneous removal of methylene blue and copper (II) ions by photoelectron catalytic oxidation using stannic oxide modified iron (III) oxide composite electrodes. J. Hazard. Mater. 2015. Vol. 293. P. 105-111.

34. N. Mohammadi, H. Khani, V.K. Gupta, E Amereh, S. Agarwal. Adsorption process of methyl orange dye onto mesoporous carbon material-kinetic and thermodynamic studies. J. Colloid Interface Sci. 2011. Vol. 362. P. 457-462.

35. V.K. Gupta, R. Kumar, A. Nayak, T.A. Saleh, M.A. Barakat. Adsorptive removal of dyes from aqueous solution onto carbon nanotubes: a review. Adv. Colloid Interface Sci. 2013. Vol. 193-194. P. 24-34.

36. P. Sharma, M.R. Das. Removal of a Cationic Dye from Aqueous Solution Using Graphene Oxide Nanosheets: investigation of Adsorption Parameters. J. Chem. Eng. Data. 2013. Vol. 58. P. 151-158. 